\title{
Steadiness of expectation theory measured by swaption curve
}

\author{
DOI: https://doi.org/10.33262/ap.v3i2.1.46
}

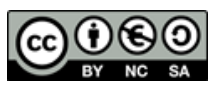

\section{La estabilidad de la teoría de la expectativa medida por la curva de swaption}

\author{
Antonio Ruben Santillan Pashma. ${ }^{1}$
}

\begin{abstract}
The financial crisis that broke out in mid-2007 has spread in the existing financial system with great instability favoring the devaluation of currencies with the fall in market interest rates. This has caused potential investors to become more risk-averse and therefore, look for financial products, although lower profitability, also poses less risk. Following this line, it is the Fixed Income assets that have acquired greater prominence in these times of crisis. This article highlights the strength of the expectation theory in different tranches, using EURIBOR rate to determine implicit forwards, and estimate the price of a one-year swap contract with 3 months of maturity, and comparing in every moment with the real prices of swap as a benchmark. SWAP is the bigger derivative inside of the group of Fixed Income Assets. After the quantitative analyst, it has been observed how the theory prevails of sceneries of low volatility but falls on sceneries when the volatility starts to increase. Introduction. One of the basic assumptions about financial theory is talking about the expectations theory. Since the middle of the eighties, this theory has been used as the unbiased estimator to calculate the swap interest rate in the base of the spot bank interest rate. Aim. Quantitativa analyst of the steadiness of expectations theory in differents economical cycles, using the European Central bank as the source to get hold of the EURIBOR spot rates for 3 months, 6 months, 9 months, and 12months from 2004 to 2016. Results. During the periods before the crisis 2007, the prices of the IRSWAP are almost adjusted between the market and what the financial theory says. The situation starts to change after the financial crisis when the volatility of the market starts to increase due to the instability of the banking sector and traders started with speculations strategies forgetting the aim of hedging, operating, new positions the majority in the short term.
\end{abstract}

\footnotetext{
${ }^{1}$ Faculty of Organizational and Management Science, Szent István University Kaposvár, Guba Sándor u. 40, 7400 Kaposvar - Hungary, e-mail: santillan.antonio@ke.hu https://orcid.org/0000-0001-6696-8127
} 
Conclusion. Whether for speculative reason or interventions actions of the monetary authority, the theory e "EXPECTATIONS THEORY", it is not an efficient predictor with out using a premium risk, during the periods of high volatility.

Keywords: Swaps, Quantitative Easing, Interest Rate, Forwards, Expectation Theory.

JEL codes: G120, G150, G170

\section{Resumen}

La crisis financiera que estalló a mediados de 2007 se ha extendido en el sistema financiero existente con gran inestabilidad favoreciendo la devaluación de las monedas con la caída de las tasas de interés de mercado. Esto ha provocado que los inversores potenciales se vuelvan más reacios al riesgo y, por tanto, buscar productos financieros, aunque de menor rentabilidad, también supone un menor riesgo. Siguiendo esta línea, son los activos de Renta Fija los que han adquirido mayor protagonismo en estos tiempos de crisis. Este artículo destaca la solidez de la teoría de las expectativas en diferentes tramos, utilizando el tipo EURIBOR para determinar forwards implícitos, y estimar el precio de un contrato swap a un año con 3 meses de vencimiento, y comparándolo en cada momento con los precios reales del swap como Un punto de referencia. SWAP es el derivado más grande dentro del grupo de Activos de Renta Fija. Después del analista cuantitativo, se ha observado cómo prevalece la teoría de escenarios de baja volatilidad pero cae en escenarios cuando la volatilidad comienza a aumentar. Introducción. Uno de los supuestos básicos de la teoría financiera es hablar de la teoría de las expectativas. Desde mediados de los años ochenta, esta teoría se ha utilizado como estimador imparcial para calcular la tasa de interés swap en base a la tasa de interés bancaria al contado. Apuntar. Analista cuantitativa de la teoría de la estabilidad de las expectativas en diferentes ciclos económicos, utilizando como fuente al Banco Central Europeo para hacerse con los tipos spot EURIBOR a 3 meses, 6 meses, 9 meses y 12 meses de 2004 a 2016. Resultados. Durante los períodos previos a la crisis de 2007, los precios del IRSWAP casi se ajustan entre el mercado y lo que dice la teoría financiera. La situación comienza a cambiar luego de la crisis financiera cuando la volatilidad del mercado comienza a aumentar debido a la inestabilidad del sector bancario y los operadores comenzaron con estrategias de especulación olvidando el objetivo de cubrir, operar, nuevas posiciones la mayoría en el corto plazo. Conclusión. Ya sea por motivos especulativos o por acciones de intervención de la autoridad monetaria, la teoría y la "TEORÍA DE LAS EXPECTATIVAS", no es un predictor eficiente sin utilizar una prima de riesgo, durante los períodos de alta volatilidad.

Palabras clave: Swaps, flexibilización cuantitativa, tasa de interés, forwards, teoría de la expectativa.

Códigos JEL: G120, G150, G170 


\section{Introduction}

According to the expectations theory and principles of non-arbitration, the interest rate swap deliver by the mark has to provide the same performance as a single investor who evaluates the derivate using forwards with spot interest rate provided by the central bank, the volatility of the swaps depends on the economic cycle, those products can be easy influenced not just but the powers of the markets, the prices can also depend by the actions of the central banks playing in the economy because in the majority of the cases they control the supply of money.

That's one of the main reasons to be able to understand the changes of the curve, investors have to study the volatility of the curve, Jacob Gyntelberg and Christian Upper (2013) had made a complete analysis about the interest rate swap market and how the market has been behaved before and after the 2007 crisis, it has demonstrated that SWAP shows positive turnover growth. The analysis was developed for different currencies EU, USD, GBP, the main turnover it continues in the developed markets, therefore, It can be assumed that the volatility in those markers can be lower, but it can be also the market it is not predictable in crisis time.

Juan Ángel Lafuente, Nuria Petit, and Pedro Serrano (2015) analyzed the causes of the different prices of the derivate because of the increasing of the risk premia, the article use a vanilla SWAP to make the analyses since the crisis of 2007 , providing the biggest changes in the prices curve is due to a level factor capturing the $90 \%$ of the movements of the prices and increasing the volatility of the deposit rate derivate is higher than deposit rate that it's complementary to the results of this paper, Johan Duyvesteyn and Gerben de Zwart (2015), the analysis of the term structure risk premia in a base of the building positions in the short and long term, shows that the volatility risk premium is shorter within short positions the risk premia don't affect the model as in long term, the analysis has been made for four markets (USD, JPY, EUR, and GBP).

Those paper and others that have been not mentioned, it supports the conclusion of these research that about the Expectations Theory, that in time of high volatile that the market increase the risk premia and that affect the valuation of the deposited rate derivate that is more volatile than the deposited rate, because of the conditions of the operations of the market the stocks markets can change the positions faster than banking markets, affecting directly in the prices of the SWAP. At the end of this article, it could be observed how the financial theory will not prevail in face of unexpected circumstances on the market, propitiating the unsteadiness of the forward as a predictor of the SWAP prices.

\section{Literature Review}

Due to the increase of the turnover of the fix income division and the instability of the market since the financial crisis of 2007, the fix income has increased in last decades with the presence of unusual fluctuations. This is the main reason why different publications appeared related to this topic. One of those papers was published by Juan Ángel Lafuente, 
Nuria Petit and Pedro Serrano (2015) analyzing the causes of the multi-curve framework using basic SWAPs spreads -floating-to-floating interest rate SWAPs as an instrument for extracting the interest rate curve differentials. Together with Johan Duyvesteyn and Gerben de Zwart (2015) they create an empirical analysis of the term structure in the volatility risk premium in the fixed income market by constructing long-short combinations of two at-the-money straddles for the four major swaption markets (USD, JPY, EUR and GBP).

One of the main strategies within the fix income division is the SWAPS what will be analyzed in this dissertation. To the analysis, the estimation and an understanding of these strategies is necessary to study the principals of the macroeconomic variable interest rates. Therefore, authors as Fatma Chakroun, Fathi Abid (2014) has been referred to who writes about "A Methodology to Estimate the Interest Rate Yield Curve in Illiquid Market: The Tunisian Case." As the title of the article says the main goal if the authors was to create a methodology to estimate the interest rate yield curve in an illiquid market like is the Tunisian bond market, with the applied method of the cubic spline interpolation.

Furthermore they focused on the work of Vasicek from the year 1977 and of CoxIngersoll and Ross from 1985, from where they got the prediction of the dynamics of the interest rate yield curve through the methods OLS (Ordinary Least squares) and the (MLE) Maximum Likelihood Estimation. The authors concluded that if the Tunisian bond market does not have a yield curve, it is because it's an illiquid market with a very small trading quantity even if we are comparing it with other countries that are also classified as developing nations, what it makes extremely difficult to get an accurate interest rate yield curve. However with the methodology that they used it was possible.

The results (empirical) shows that with the using of the cubic spline method was the best solution for a market with low level of trading, and it was possible to build an accurate average yield curve that indicates that the spread between the long-term and the shortterm yields is pretty small what can cause a predictable high inflation. Finally, they ensure that the methodology that they used can be very useful to create the monetary policy for a country, and for the financial institutions it can be very helpful in order to predict in trading activities the losses in the case of disadvantageous movements of the interest rates.

In association with the findings of the analyses of the interest rate is to be continued with Yacine Ait Sahalia, Mustafa Karaman, Loriano Mancini (2013) describe in the article "The Term Structure of Variance Swaps and Risk Premium" the analyses of the term structure of three components: variance swaps, equity and variance risk premium. They compared the Variance Swaps and the Volatility Index, and they concluded that in the case of Variance Swaps there is an important element: the time-varying jump risk. Secondly based on their own model, they affirm that the term structure of variance risk premium can be characterized for being negative and normally downward sloping what it has as a consequence that the short-end of term structure shows the fear of the investors on a market crash, they are more afraid of the impact of random volatility on the investment set. 
In the case of the term structure of the equity risk premium, they defined it as countercyclical but with a procyclical slope. To conclude, the equity and variance risk premium term structures react almost evenly to current economic indicators. The aim of the authors Ravi Bansal, Hao Zhou (2001), in their article "Term Structure of Interest Rates with Regime Shifts" is to show through a model how the regime shifts can affect the entire term structure of interest rates, even when there are another works that prove that before these term structure models with regime shifts were developed in 1997 by Nail and Lee and in 1998 by Evans.

There is one important difference, because Bansal and Zhou studied how the regime shifts also affect the framework that controls the market prices of risk. They conclude that the main goal of their work is to prove that this is an efficient model because it takes into consideration the regime shifts as a vital part for the conditional joint dynamics of short and long yields and that there is a strong connection among the business cycles and regimes shifts. Continued with the capital prices Jacob Gyntelberg, Christian Upper (2013), had developed a complete analysis about the interest rate swap market after the 2007 crisis, finding a low but stable interest rate with low but positive turnover growth. The analysis was developed for different currencies (EUR, USD, GBP), in spite of the fast growing of different developing countries the main markets are still situated in the oldest markets.

At the beginning of the article , "The OTC interest rate derivate market in 2013", the authors mention that in order to analyze the market for OTC (over-the-counter) interest rate derivate they are using the data from the Triennial Central Bank Survey. In the first years of the 80s this market has grown enormously and during the 1980's and at the middle of the 2000's was stable however in the last years has suffered a lot of changes and the main reason of that are the regulations in order to make a market more transparent and decrease the counterparty risk. The main changes have been the increasing share of transactions that at now is centrally cleared, the declining role of the inter-dealer market because at now they trade less amount than before what at the end will have consequences for market liquidity .

There is a positive side and a negative on this. The positive is that this kind of new regulations will reduce the counterparty risk and the negative side is that the over regulation will make in this market that the trading will cost more. Regarding the negative part Robert N McCauley (1999) examined the effect of the introduction of the euro on the liquidity of European fixed income markets.

\section{Interest Rate SWAP}

The temporary interest rate structure, as a relationship between the different interest rates existing in a market, and depends on the term in which they are applied, daily, monthly, annual, etc. A continuous term structure could be observed directly from the public debt market for each asset with zero-coupon security without credit risk. However, only a finite number of titles are available in the market. The usual list is 3 months/period, 6 
months/period, 1 year/period in short term, and bonds of 10 years/period and their prices are defined for a finite number of points that the analyst can use to build a temporal yield (pag16, we can observe the curve).

Most of the titles that are on the market pay coupons periodically, the credit quality of these bonds depends on the risk market, liquidity, and other factors that can affect directly or indirectly the value of the asset on the market (John C Hull, 2005). How has been defined the credit quality of the title depends on the market where the title is operated. Thus, traders and analysts use the prices of the titles of countries that are considered secure, due to the low inflation, standard growth, low level of debt to estimate the prices of their public debt assuming that the titles from countries are not exposed to credit risk. In the eurozone, it is used the prices of the German bond (Mario Bajo Traver and Emilio Rodríguez Alfonso, 2005)as a reference price of titles free of insolvency risk.

In Figure 4, It can be observed how sovereign bonds are the zero risk bonds, pay a very low-interest rate but are assets free risk, while corporate bonds are normally rated by different risk agencies (Standard \& Poor's, Fitch Group, Moody's), are bonds with a higher level of probability of default but the yield that could generate is higher to the holder in case of payment compliance.

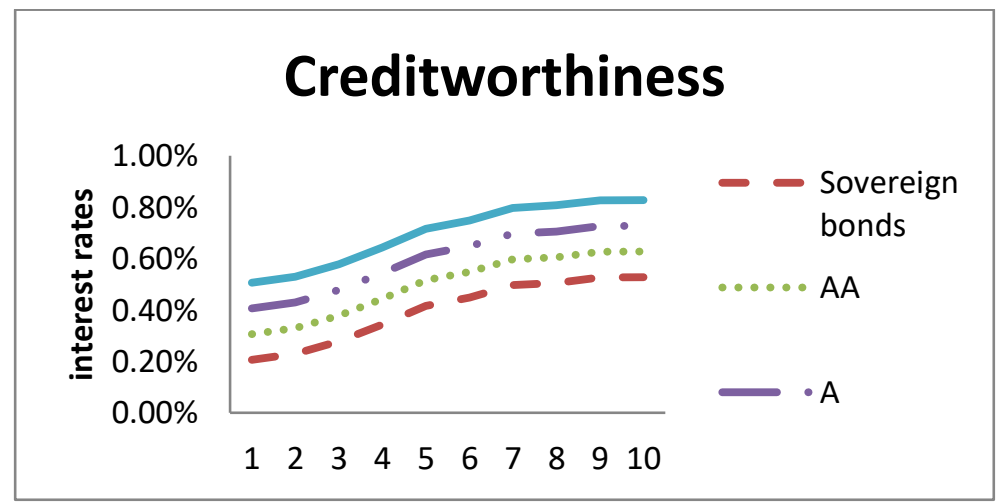

Source: LIBOR 2015

Figure 1 Term structure rate by Credit Risk

Within the fixed income market there are different types of interest rate curves, spot, forward, SWAP (Eliseo Navarro and Juan Nave, 2001).) but the most significant on the market is the spot or cash curve. The spot curve can be estimated by observing the daily interest rate on market, although; it is relatively easy to estimate one curve using another. There are different analytics possibilities to estimate the term structure of the interest rates, using discreet models or continuous models (Vasicek, Svensson, Cox-Ingersoll, and Ross).

However, it is necessary to provide an introduction of the interest rate yields; there are different authors which can get the readers into a deep of knowledge of how to estimate the different curves, for example, Fatma Chakroun and Fathi Abid 2014), as it was mentioned before using continues models (Vasicek 1977), and Cox-Ingersoll and Ross CIR 1985)). It is not the purpose of this dissertation to analyze the yields, even though, It is going to be mentioned in the following sections a brief explanation of basic terminology 
necessary to understand the operationally of the markets and the movements of the interest rates. Modeling of the different curves is carried out by the monetary authority of each country, central banks. It should be noted, the estimation of the term structure of interest rate depends to a great extent on the results and the reasons why the one being modeled and although in all cases the results are similar, it cannot be said that there isn't a uniform estimation. For our analysis, we will use the (Svensson 1994) model to investigate the behavior of various curves of interest rates after having analyzed the volatility of the price of the Swaps and understand how the market has behaved at each moment.

Depending on the market and the moment, it can be observed different types of curves and each of them depends on the risk of involvement and an inversely proportional relationship can be observed with a higher risk of insolvency, lower credit quality and therefore the bond offerors will have to pay a higher interest rate to make your asset more attractive to investors (Ravi Bansal and Hao Zhou, 2001). It should be noted that depending on each case, the term structure of interest rates can take different forms, thus a flat structure can be appreciated, which informs us that the interest rate is unique for any type of maturity. A decreasing structure when short-term interest rates are higher than long-term interest rates (eurozone crisis 2012), a growing structure that the most common, the time value of money plays an important role and therefore the interest rates to shortterm rates are lower than long-term rates

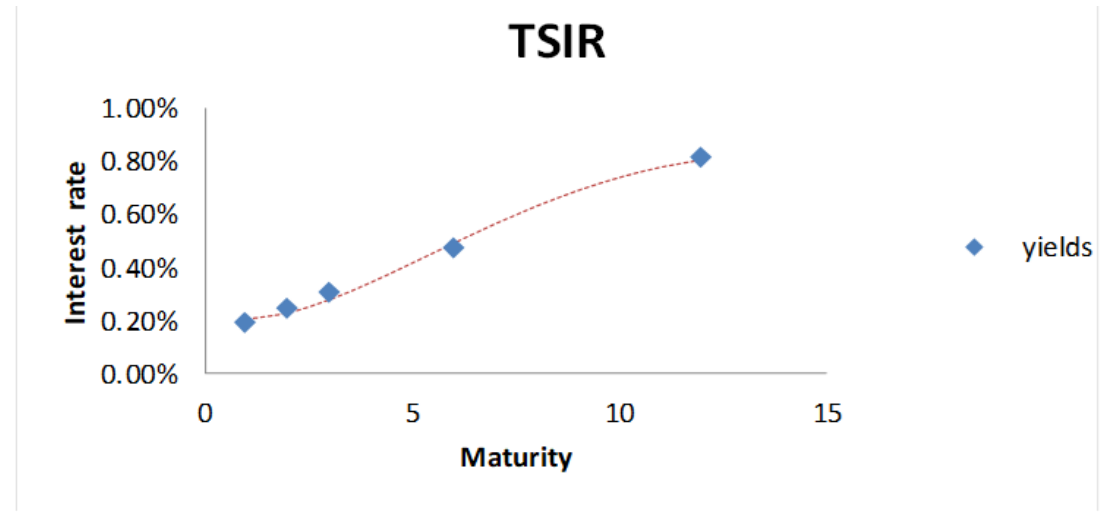

Source: LIBOR 2015.

Figure 2 Term structure of interest rates

For another hand, to estimate a Term Structure of interest rates (TSIR for now on), it is necessary to know which it is the returns of the financial assets that operate on the market, understanding the yield as the average rate of return that an investor will receive, if they held the asset until the maturity of the operation. The valuation of a bond in the market is given by the following expression (Eliseo Navarro and Juan Nave, 2001):

$$
p=\sum_{i=1}^{n} \frac{c}{(1+i)^{n}}+\frac{M}{(1+i)^{N}}
$$

Equation 1 


$$
\begin{gathered}
\mathrm{M}=\text { value at maturity } \\
\mathrm{c}=\text { coupon } \\
\mathrm{i}=\text { interest rate } \\
\mathrm{n}=\text { number of payments }
\end{gathered}
$$

Where the price $\mathrm{p}$ of the bond is in the function of the periodical payments expressed as a coupon $\mathrm{c}$, the required interest for assuming certain risk i, and the number of payments that the owner of the bond will receive $n$. The prices of the bonds can build a TSIR finding different bonds with different maturities and similar risk as it was commented the governments are the most popular instruments to build a TSIR. Depending on the term of the bond, the level of profitability required changes, in the long term the yields are higher, while in the short term the yields are lower because of liquidity premiums.

Fixed income markets depend on the type of assets that are traded on them, it can be distinguished as money markets (with debt at short term and little risk or high liquidity) and capital market (to negotiate debt with medium and long-term maturity). These are the most important and necessary segments of the market where the financial analyst operates with interest rates. In these circumstances, spot and forward rates acquire greater importance. It can be denominated as spot rate to the discount rate at the current time. Spot interest rates can be observed in the wholesale market where only, credit institutions are involved. It allows, among others, to establish the price of money through the loans that financial institutions make between them (generally in terms of one day or one week). In the eurozone is where basically according to intraday operations the financial authority European Central Bank sets the spot rate, named EURIBOR rate as the average of the rate with which eurozone banks carry out commercial exchanges. If the financial operation is executed in the future the expected discount rate at a future time of the asset is demonized forward rate (Eliseo Navarro and Juan Nave, 2001).

In Figure 3 it can be observed the financial operation in $t=0$ with the knowing interest rates and another operation traded in $\mathrm{t}=0$ with an unknowing discount factor that will be done in $t=1$ with the expected interest rate based on the interest that is today.

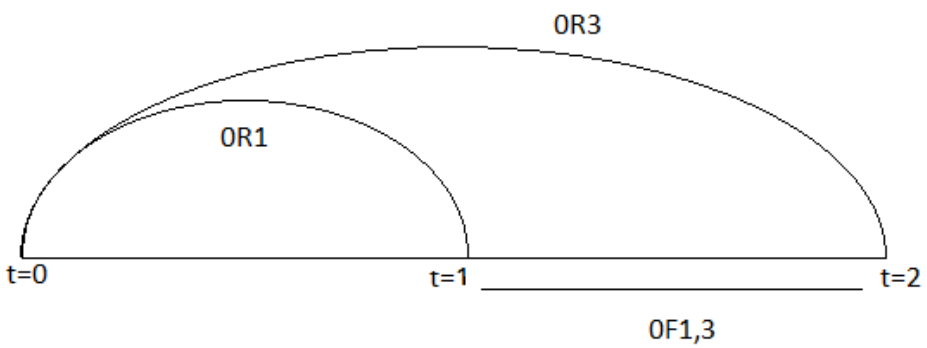

Source: John C Hull, 2005.

Figure 3 Forward Expression

The relation between spot rate and forward rate can be expressed with the following equation, where Let to $R_{t 1}$ and to $R_{t 2}$ be the current spot rates at $t_{0}$ for the periods $\left[t_{0,}, t_{1}\right\rfloor$ and 
$\left\lfloor t_{0}, t_{2}\right\rfloor$. Then, It can define the implicit interest rate or forward in $t_{0}$ that belongs to the term $\left\lfloor t_{1}, t_{2}\right\rfloor$ that fulfills the following expression: $\mathrm{t}_{0} \mathrm{~F}_{\mathrm{t} 1, \mathrm{t2}}\left(\mathrm{t}_{0}<\mathrm{t}_{1}<\mathrm{t}_{2}\right)$,

$$
\left(1+R_{0 . t 2}\right)^{t 2}=\left(1+R_{0 . t 1}\right)^{t 1} *\left(1+F_{0 . t 1, t 2}\right)^{t 2-t 1}
$$

Equation 2

Where:

$$
\begin{aligned}
& R_{0 . t 2}=\text { Spot Interest from } \mathrm{t}_{0} \text { to } \mathrm{t}_{2} \\
& R_{0 . t 1}=\text { Spot Interest from } \mathrm{t}_{0} \text { to } \mathrm{t}_{1} \\
& \mathrm{~F}_{0 . \mathrm{t} 1, \mathrm{t} 2}=\text { Forward Interest from } \mathrm{t}_{0} \text { to } \mathrm{t}_{1} \mathrm{t}_{2}
\end{aligned}
$$

Note that the forward rate is the one-year spot interest rate that should be valid within one year so that the result of the two-year investment produces the same result as investing successively at one year and reinvest the result for one more year. A very important property and where this analysis is focused is that forward rates, so that there are no arbitrage opportunities, should coincide with future rates but If the interest rate estimators are not unbiased, we see that there are arbitrage opportunities (Eliseo Navarro and Juan Nave, 2001).

Intuitively, the forward interest rate corresponding to a certain term $\left\lfloor t_{1}, t_{1}\right\rfloor$ is nothing more than the spot interest rate that should be in effect at $t 1$, so that the result of an investment in the term $\left\lfloor t_{0}, t_{2}\right\rfloor$ generates the same result as investing in the term $\left\lfloor t_{0,}, t_{1}\right\rfloor$ and reinvesting the resulting amount in a second operation at an extended-term $\mathrm{t} 2$ - $\mathrm{t} 1$.

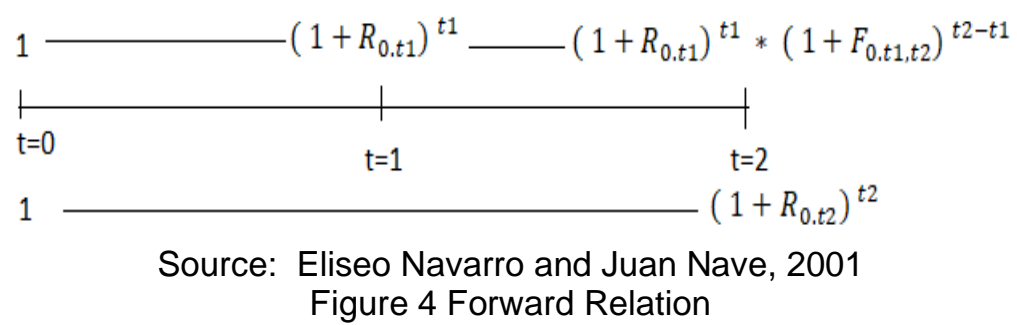

To avoid the risk of reinvestment financial entities use "zero-coupon rates" to value monetary flows and calculate these interest rates that provide the implicit rates. These interest rates are not obtained in the financial market, since they do not exist for longterm time horizons, so it is necessary to start from the price of other highly liquid assets (government bonds, interbank rates, swaps, etc.), with different maturities. One of the possibilities to estimate the zero-coupon yield is using models as Vasicek y Fong (1982), Modelo de Nelson y Siegel (1987), and the Svensson (1994) model.

The interest rate that of any financial asset as a bond, FRA or SWAPs pays always moves against its performance. This is logical if we understand the price of the asset as a function directly related to the periodic payments that the owner of the SWAP (one of the most common assets in the financial market) has the right to receive. If we believe that interest rates are going to fall, older SWAPs (and therefore that are offering higher coupons than expected) will have more value. Conversely, if we believe that market interest rates are 
going to rise, old SWAPs will lose value (as they will be offering lower payments than new issues are expected to do).

\section{Methodology and Data}

With the generation of the MATLAB code. This article discusses the relevance of the financial theory during the time or changes in the curve of the interest rate due to causes beyond the normal operation of market, Juan Ángel Lafuente, Nuria Petit, and Pedro Serrano (2015) have proved that the difference of the swap prices is due to the volatility of the risk premium proving that the valuation of the derivate is highest sensitive to the conditions of the markets, based on this the results of this research confirm that the financial theory does not prevail in times of extreme volatility because the theory of expectations it is not consistent, forwards are not unbiased estimators of the future spot rates. Affectation the following hypothesis the analysis has begun: Forwards are not good predictors of the swap rate, under cases of high volatility - "Theory of expectations does not prevail", banking market is less volatile than the stock market, hedging strategies change by speculative strategies increasing the volatile of the market. In a conjunctural moment like the present, in which there has been a strong financial crisis caused by the COVID-19 pandemic, economic agents will begin to see swap products as allies in managing the risks of their economic activity, only to the extent that the benefits are fully understood and the risks inherent in these structures, their scope, and limitations.

Focusing on a quantitative approach using the European Central bank as the source to get hold of the EURIBOR spot rates for 3 months, 6 months, 9 months, and 12months from 2004 to 2016. The interest rate database will be depurated confronting the swap prices that will be mentioned after, to eliminate from database those days without transaction in the market, where either will be interest rate but will not be swap price or will be swap price but not the interest rate. Excluding for this analysis the not trading days because of the weekend, holidays indeterminate market or days off of the main actors of the market due to unexpected events such as the stoppage of the transaction by government order, for example in the middle of 2007.

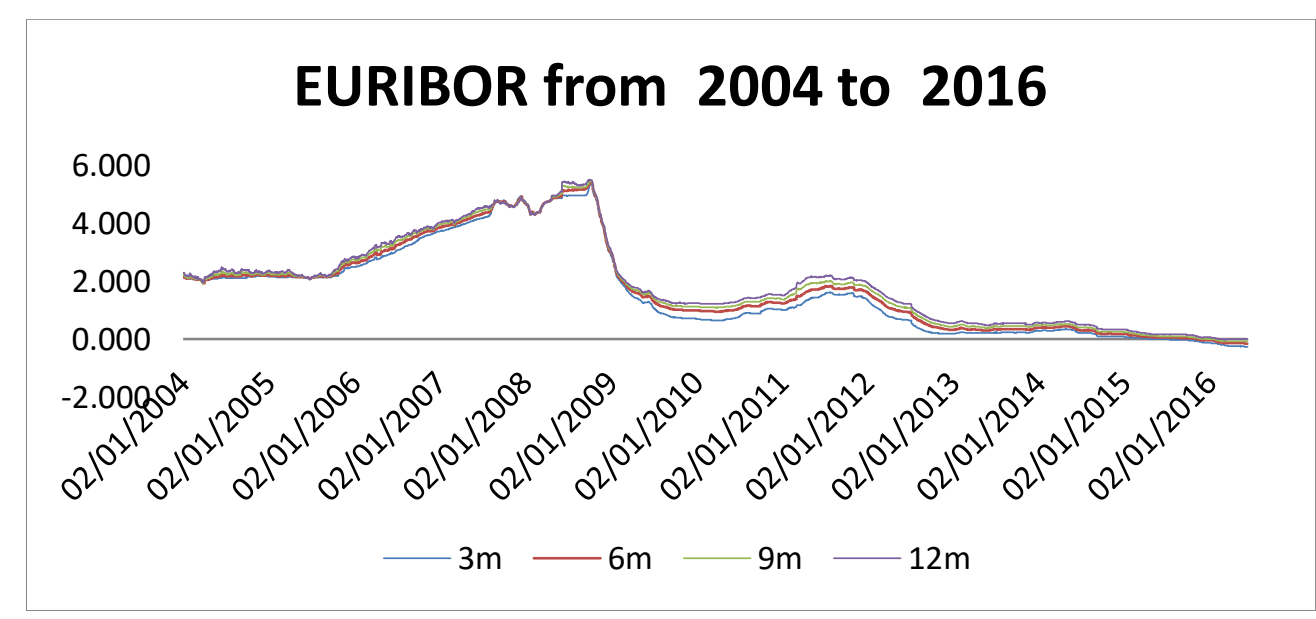

Source: European Central Bank

Figure 5 EURIBOR from 2004 to 20016 
Once the term structure of interest rate has obtained with different maturities as 1 month, 6 months, 1 year, 2 years 5 years, and 10 years ( the most common points on the yield), the equivalence equation will be used to calculate will continue with the extrapolation of the forward's rates using the equation number two mentioned before on this dissertation. The equation will allow the research to use the spot rates to calculate the forward's rates as part of the financial theory, where spot rates are unbiased estimators of the forward's rate using the theory of expectations (John C Hull, 2005).

The theory of expectation affirms that a spot rate contains information of the expectations of the investors about the spot rates that governments will use in the future (Lutz, 1940), the expectation theory was developed based on excessively restrictive hypotheses, the theory has the idea that economic activity takes place in an environment of absolute certainty, and there is not asymmetric information between counterparties and that fixed income securities with different maturities are perfect substitutes, for example, investing in a two-year zero-coupon bond is equivalent to Invest in a one-year non-coupon bond and renew that investment again. This theory will be disputed based on the results of this dissertation.

To demonstrate the weekends of the expectation theory, It is going to be compared as a benchmark the price of three months interest rate swap one year of maturity (SWAP3m1Y ) from 2004 to 2016 (SWAP prices rates will be obtained in Blomberg which is made in the market with their intraday operations), with the estimation of the prices that will come using forwards rate and fitting those rates into the equation three (John C Hull, 2005).

How it was mentioned and develops in chapter one of this dissertation, the swap is a contract that allows the transactions of cash-flow with not capital movements; the derivate permits two counterparts to exchange cash-flows originating by loans or in some cases for investments. The most common SWAP is the plain vanilla, where one of the counterparts assumes a fixed position or fixed leg where they have to pay a fixed interest rate and the other counterpart assumes the floating position or floating leg having to pay a floating interest rate.

At this point, it has to clarify that the notional of the contract always remains constant, and the only payments which are transferring between the counterparts are the deference the amount of money that it has to payments for the fixed leg and the amount of money that the floating leg has to pay.

$$
\begin{gathered}
\sum_{i=1}^{n} M * F_{t}\left(\frac{T_{k i}-T_{k(i-1)}}{360}\right) * d f=\sum_{i=1}^{n} M * \operatorname{Iswap}\left(\frac{T_{k i}-T_{k(i-1)}}{360}\right) * d f \\
I S W A P=\sum_{i=1}^{n} M * F_{t}\left(\frac{T_{k i}-T_{k(i-1)}}{360}\right) * d f / \sum_{i=1}^{n} M *\left(\frac{T_{k i}-T_{k(i-1)}}{360}\right) * d f \\
\text { Interest Rate SWAP }
\end{gathered}
$$

Equation 3 
Where:

M: Capital with which the contract is opened.

Ft: Forward rate in the ti period.

Df: Discount factor for the ti period.

Once the valuation of the swap will be completed and with the expectation of a better understanding of the situation what is happening with the swap prices and with the European economy. It will analyze the prices dividing the time series into different parts one part will be from 2004 to 2005 when the conditions of the market were stable, the second part will start with the financial crisis of 2007 and the fall of Lehman Brothers, the third will be once the bank nationalizations started in united states, the fourth part will focus when the market starts the attack against the euro and it will end with the applications of quantitative easing policies in the eurozone. In order to provide a better explanation, it is going to be necessary to estimate the yield curve for each scenery, intending to use the TSIR theory to have a better explanation of what happened in the market.

The estimation of the yield curve will be developed using the Svensson model 1994, the model proposes to estimate the parameters of the zero-coupon curve minimizing an adjustment measure such as the sum of squares of the error on spot prices. The estimation is carried out employing maximum likelihood, non-linear least squares, or the generalized moment method.

$$
\begin{aligned}
R_{t}\left(t_{i}\right)= & \beta_{O}+\left(\beta_{1}+\beta_{2}\right) \frac{\tau_{1}}{t_{I}}\left(1-e^{-t_{i} / \tau_{1}}\right)-\beta_{2} e^{-t_{i} / \tau_{1}}+\beta_{3} \frac{\tau_{2}}{t_{i}}\left(1-e^{-t_{i} / \tau_{2}}\right) \\
& -\beta_{3} e^{-t_{i} / \tau_{2}}
\end{aligned}
$$

Svensson Model (1994)

Where:

Equation 4

It has to estimate six parameters via a least-squares or similar algorithm: $\beta 1, \beta 2, \beta 3$, and,. For $\mathrm{m}$ observed yields with different maturities $\tau 1, \ldots, \tau \mathrm{m}$.

$$
\beta_{O}>0 ;+\left(\beta_{1}+\beta_{2}+\beta_{3}\right)>0 ; \tau_{1} \tau_{2}>0
$$

The formula of Svensson will be used in this dissertation to compare the different changes in the slope of the curve of the interest rate in different economic circumstances, which will be important to understand the consequences of the contraction and growth.

\section{Results}

Considering that Bloomberg provided the stock market prices of SWAP with real operations prices, has been compared the estimation made with the forwards using EURIBOR rates (Figure 6), it can be observed the time series of swap prices that are 
negotiated on the market from 2004 to 2016 coming from Bloomberg (blue line) that it is performing as be the benchmark of the estimate swap prices as a result of the estimation of this dissertation (red line). During the periods before the crisis 2007, the prices of the IRSWAP are almost adjusted between the market and what the financial theory says about forwards that are unbiased estimators of the prices of the future rate for that reason the predictions made in this dissertation coincide with the real prices using by traders to operate into the stock market.

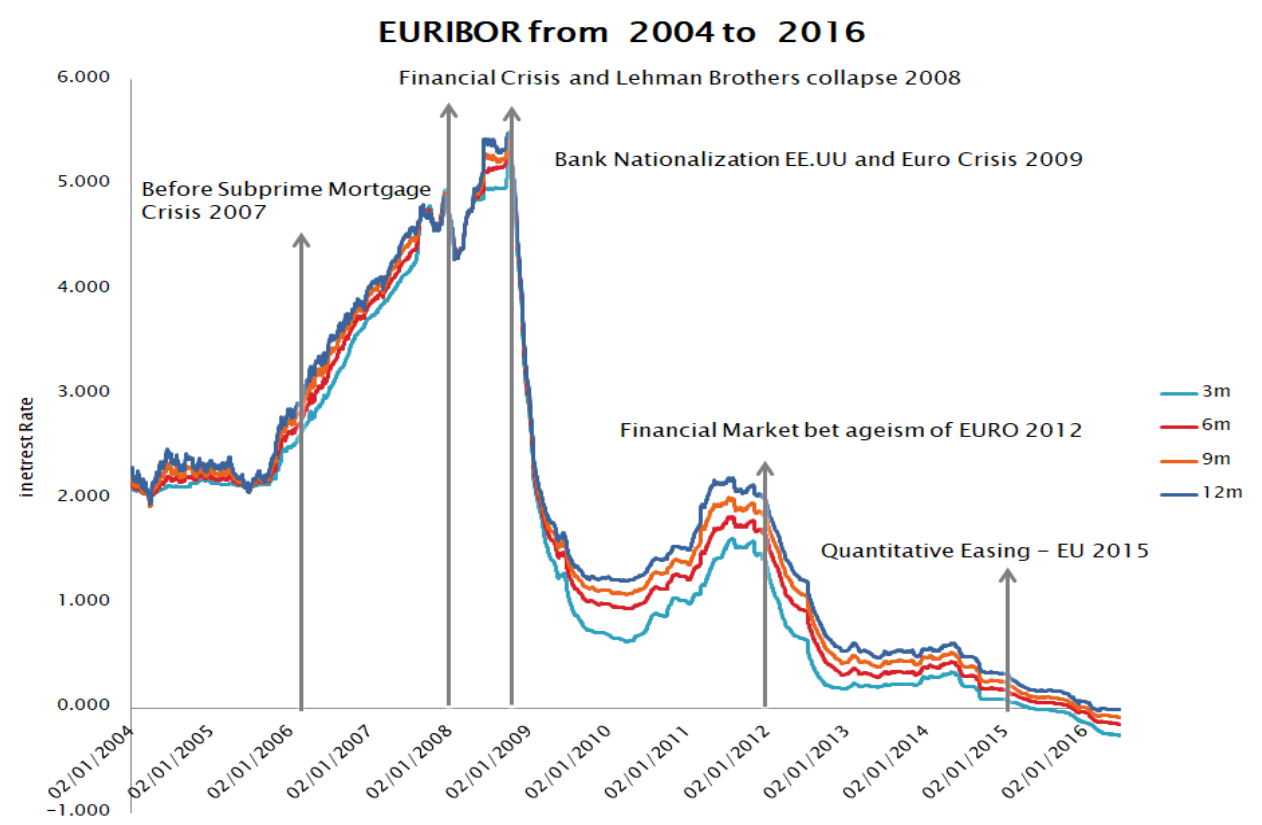

Source: Based on Matlab Simulations

Figure.6 Economic Singularities on the market.

The situation starts to change after the financial crisis when the volatility of the market starts to increase due to the instability of the banking sector and traders started with speculations strategies forgetting the aim of hedging, operating, new positions the majority in the short term with the objective of increase their performance started to concentrate the majority of the transactions increasing the volume of turnover. Jacob Gyntelberg and Christian Upper (2013) had explained that the volume of turnover has increased in the last 10 years using IRSWAP and one of the reasons that could explain why it has increased is because the volatility of the market has attracted to concentrate investment of speculative investors in this product.

However, to not go from our hypothesis we can distinguish two different scenarios, the first is when the risk premium does not affect the valuation of the IRSWAP and the theory of expectations prevail, and the second scenery when the financial theory falls and the risk premium affects the valuations of this derivate as was mentioned (Juan Ángel Lafuente, Nuria Petit and Pedro Serrano 2015), observed Figure 7, where it can divide the time series into 5 parts first before of 2007, second part Bank Nationalization USA and EURO Crisis 2009 and finally Financial Market bet against of EURO 2012, in the last part with the Quantitive Easing Policies the volatility of the market has been reduced and the differences between prices are not significant. 


\section{Analysis of Different Sceneries}

\section{Before Subprime Mortgage Crisis 2007}

Stable economic environment stable, the negative slope of the curve, a strong initiative to short-term investments, not a dynamic market, low volatility. The estimated yield curve matches with the prices of the market. The prices of the swap were stable from 2004 to 2005 due that the volume of negotiation of this product in the market was not popular and the stable conditions of the market with any didn't disruptive elements that can affect the negotiations and the interest rate it is noted that the real prices are almost equal than the estimated prices. It can be confirmed that expectation theory prevails and spot rates are transferring information to the investors about the future prices of the swap. Spot rates are unbiased estimators of the forwards and forwards are unbiased estimators of swap price the aversion of risk of the market agents is stable.

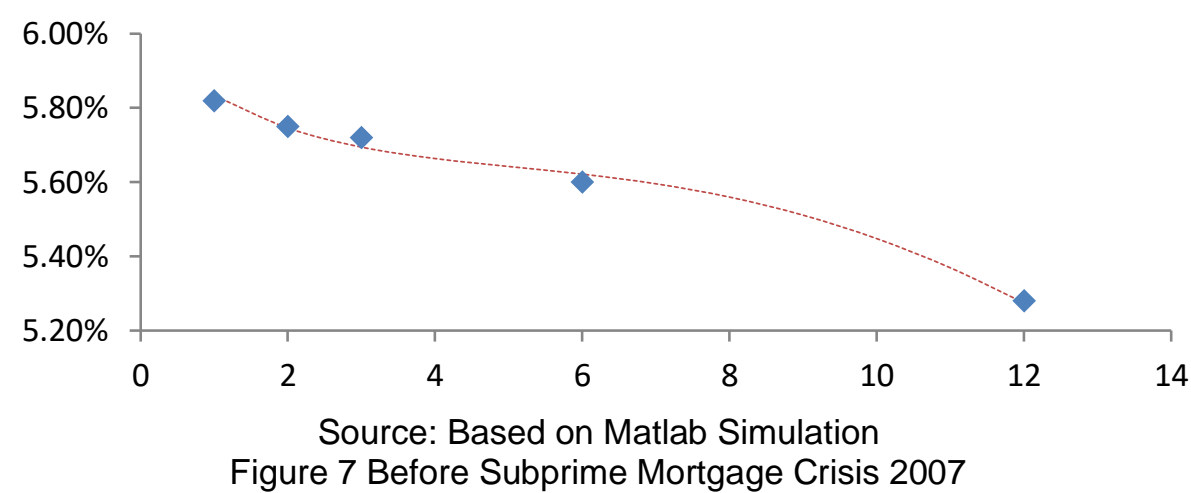

According to financial theory, the appearance of curves with negative slope is a signal of the changes in cycles of the economy and anticipated recession are coming to the economy.

\section{Financial Crisis and Lehman Brothers collapse 2008}

Uncertainty in the market, increased interest rates, increased market Volatility. After the crisis of 2007 and with the fall of Lehman Brothers in the United States the prices of the swap have fallen in both time series and it begins to see a difference between the prices traded on the market and the estimation prices. Due to that conditions of the market has changed and there are more instability and unknowing conditions of the future the government and investors have the idea that unexpected events will come and the spot rates can't provide accurate information to the model and the predictions are not exact but even though the with the information that is in the market the estimation doesn't much inexact. 


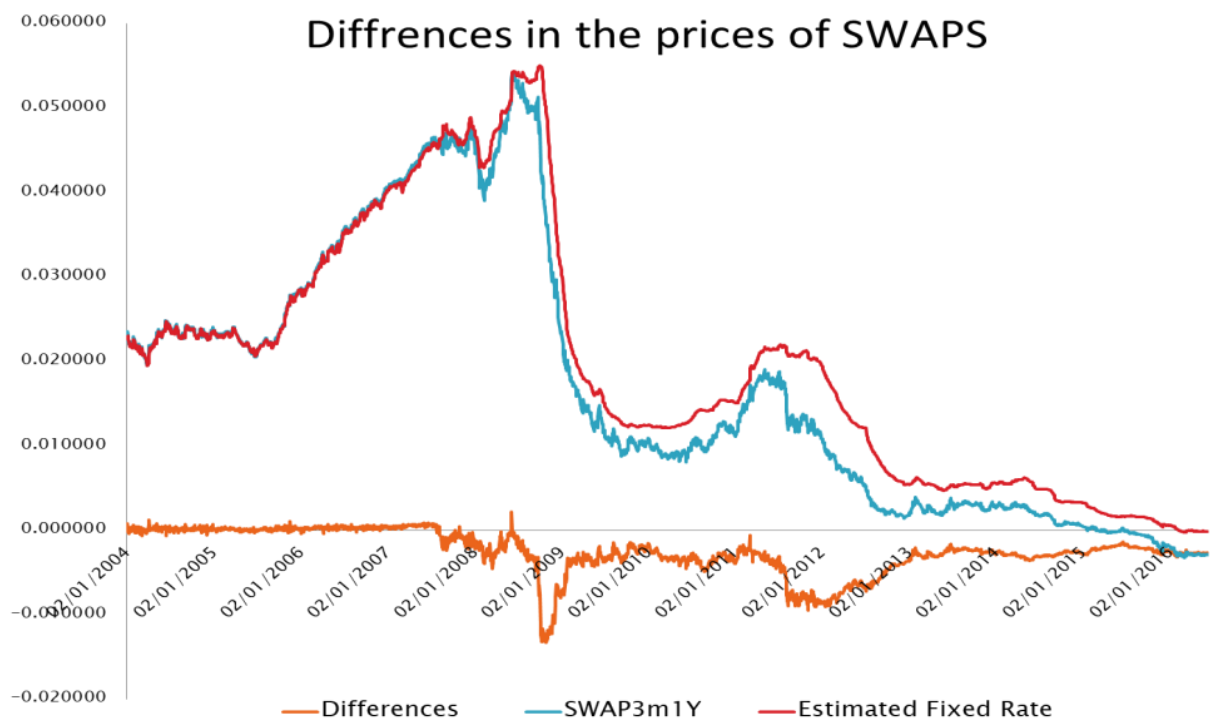

Source: Based on Matlab Simulation

Figure 8 Differences in the prices of SWAP.

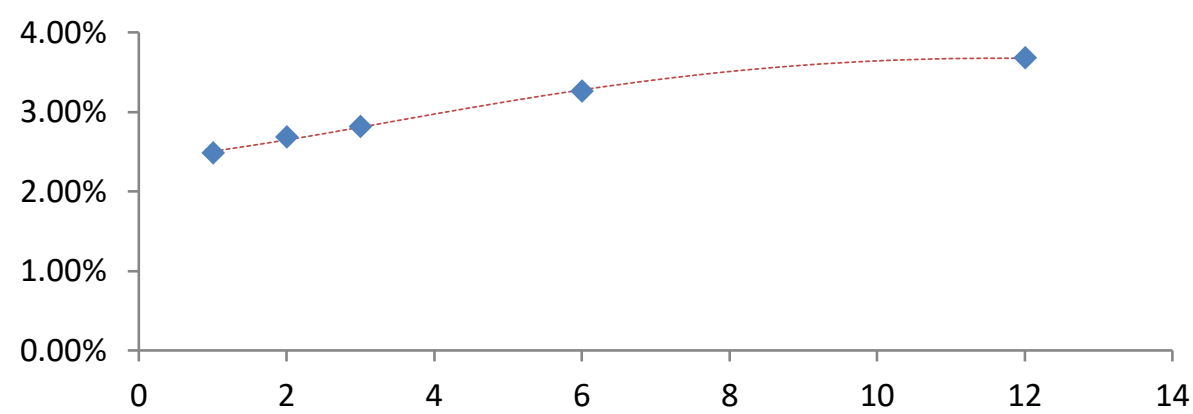

Source: Based on Matlab Simulation

Figure 9 Financial Crisis and Lehman Brothers collapse 2008.

\section{Bank Nationalization EE.UU and Euro Crisis 2009}

Drastic fall in interest rates bank panic. Central banks try to maintain the level of monetary circulation, rates are at historic lows. As a consequence of the changes in the market, the slope of the curve remains positive following the economic theory about risk aversion, which says agents are not expected big changes in the short term that is the reason that risk of the asset is low and lower return and investor has to receive more returns for assets in long term.

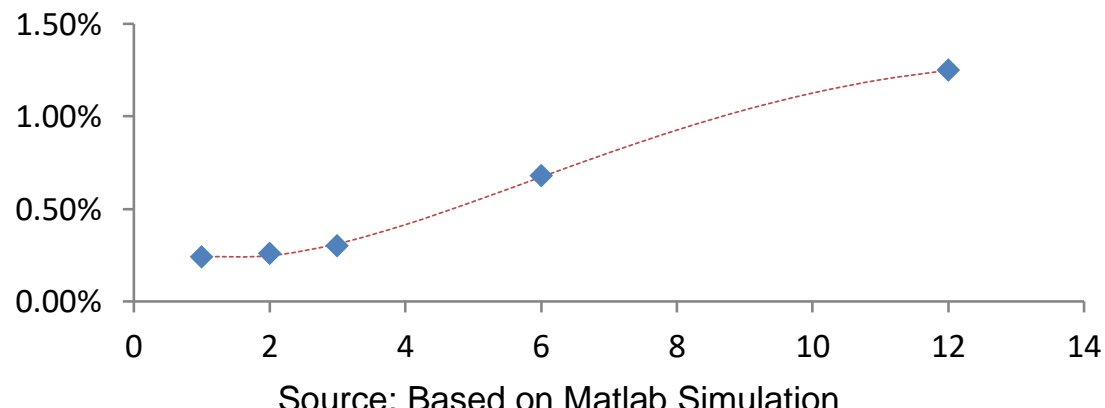

Figure 10 Bank Nationalization EE.UU and Euro Crisis 2009. 


\section{Euro Crisis}

The financial market bet against the euro, the sovereign debt crisis, the banking system, and the economic system in general. In 2012 markets start to bed against the euro and the eurozone increasing the idea the unexpected circumstances will come to the market increasing the volatility of the swap prices. That is why spot rates can't transfer accurate information to the forwards and the model is not able to estimate the correct swap prices as can be observed in Figure number 24, at this point of this dissertation it can be concluded that one of our hypotheses has been contrasted, the theory of expectations doesn't prevail under increases of volatility in the market and spot rates are not unbiased estimators of the forwards.

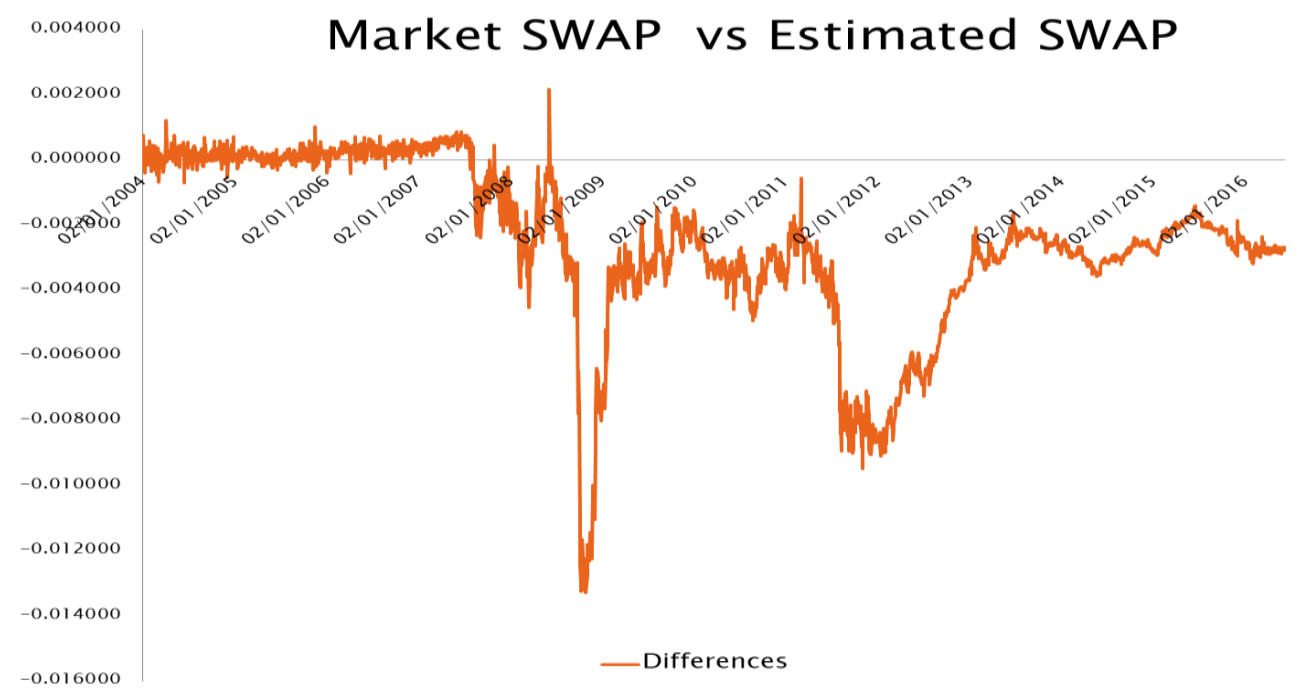

Source: Based on Matlab Simulation

Figure 11 Differences in the prices of SWAP in percentages.

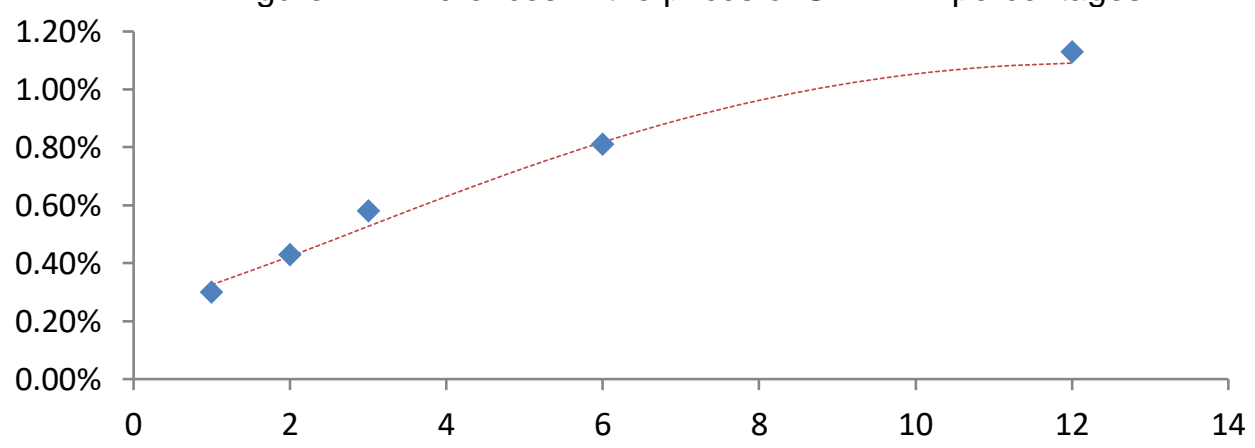

Source: Based on Matlab Simulation

Figure 12 Euro Crisis 2012.

\section{Quantitative Easing - EU 2015}

The European central bank intervenes in the economy, with massive purchases of public and private debt valued at about 60,000 million per month until at least September 2016. The massive purchase of debt stabilized the market prices and transferred stability to the market reducing the discrepancies between the observed prices and the estimated prices, providing to the spot rates more information to generate better estimations but it is not 
sufficient to come back to normal activity before the crisis of 2007 where the prices were accurate to the observed in the market.

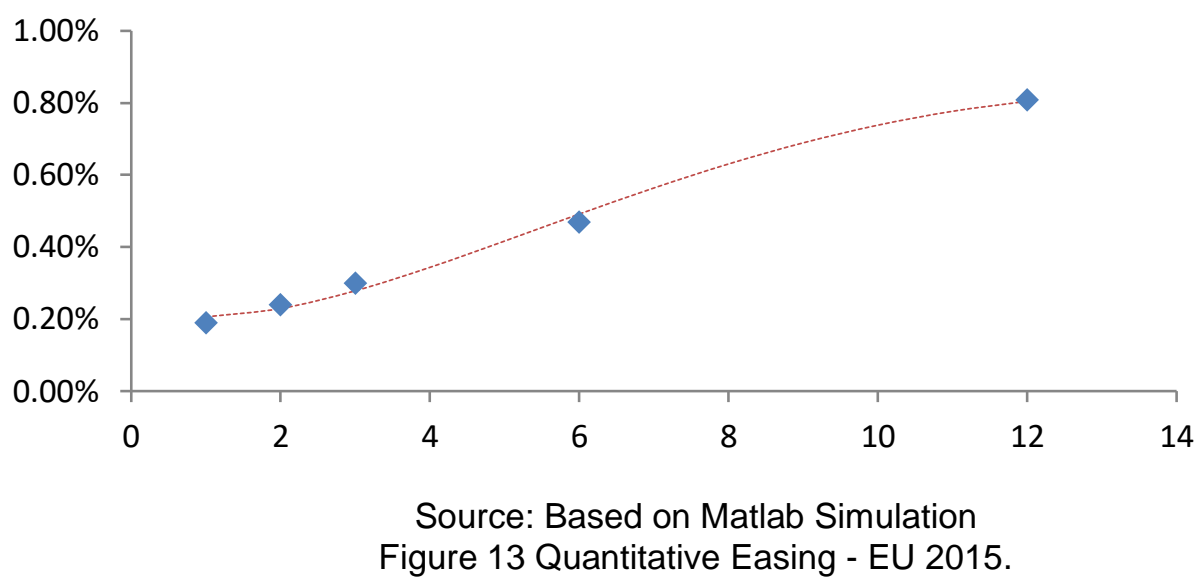

\section{Discussion and Conclusion}

In this research we can appreciate that volatility is one of the major parameters to take into consideration to evaluate any derivate, basically, the theory of expectations which affirms that forward rate is an unbiased estimator of the future spot interest rate, are not consistent during volatility periods this is one of the biggest results that we can observe with the modeling of our data, being consistent with Juan Ángel Lafuente, Nuria Petit And Pedro Serrano (2015) that affirms that the risk primea start to increase in times where the volatility of the market cannot be projected because of the turbulences of the market affecting the price of the derivate.

Whether for speculative reason or interventions actions of the monetary authority, shifting the interest curves to other levels unpredictable for the market analyst, but the financial theory especially "EXPECTATIONS THEORY", not come to meet and forward as a forecasting tool to become inefficient predictor with our using of the premium risk, during those periods to correct differences between models being the main aim to make real predictions using another econometric tool like Montecarlo Simulation, to advice traders when they have to correct the positions.

The monetary market is more volatile than the stock market, one of the main reasons why SWAP financial products have emerged is undoubtedly the limitation found in other derivatives such as futures, options, which are derivate negotiable within exchanged markets. SWAP as a forward has the peculiarity of being an open instrument, where the partners are free to negotiate the terms of the contract, such as the interest rate to be applied, the maturity of the contract, the amounts of negotiation, periodicity payments, among others and significant advantage using SWAPs the capital never exchanged just exchange interest rates cash-flows.

Thus, an investor willing to extend the performance of his portfolio, and consider that interest rates do not behave logically and will be reduced in the future, by the application 
of monetary adjustment policies from banks central (quantitative easing), a trader may enter an IRSWAP with a variable position, which certainly can get to beat the market performance, because the market expects that the interest in the future has to be higher than the current interest rate.

Traders in that case then have to generate new expectations about interest rates, and those new expectations can move Term Structure Of Interest Rates (TSIR), makes reduce the interest rate with those movements the traders can positioned in long (buy) or short (sell) according to with the new expectations of the curve. Once the trader has determinate the new expectations of the curve the interest rate, he has to develop new strategies which allow managed a portfolio with a better profile than the profit of the market.

\section{References}

Big Banks Accused of Monopolizing Interest Rate-Swap Market Available (2015): https://www.bloomberg.com/news/articles/2015-11-26/big-banks-accused-ofmonopolizing-interest-rate-swap-market

De La Torre Gallegos, A (1996): Operaciones de permuta financiera (swaps). Editorial Ariel, Barcelona.

De La Torre Gallegos, A (1996): Qué son y cómo funcionan los swaps. Revista HARVARD-DEUSTO Finanzas y Contabilidad, nº 11, Mayo-Junio.

Fatma Chakroun, Fathi Abid (2014), A Methodology to Estimate the InterestRate Yield Curve in Illiquid Market: TheTunisian Case

Financial Stability Board (2014): "Reforming major interest rate benchmarks".

Available (2016): https://www.bloomberg.com/news/articles/2016-05-06/goldman-saysit-was-named-in-interest-rate-swap-antitrust-case.

Hernández, C. (2014). Efectos Asimétricos de Shocks Fiscales en el Ciclo Económico.

Ho, T.S.Y. and S.B. Lee (1986), 'Term Structure Movements and Pricing Interest Rate Contingent Claims', The Journal of Finance, 41(5): 1011-29.

Hull, John C. (2006). Options, futures and other derivatives.

Hull, J. and A. White (1990), 'Pricing Interest-rate Derivative Securities', The Review of Financial Studies, 3(4): 573-92.

Hernández, C. (2014). Efectos Asimétricos de Shocks Fiscales en el Ciclo Económico.

Jacob Gyntelberg, Christian Upper (2013), The OTC interest rate derivatives market in 2013

Johan Duyvesteyn - Gerben de Zwart - 2015, Riding the swaption curve 
McCauley, R. (1997): The euro and the dollar.

McCauley, R and P Wooldridge (2016): "Exchanges struggle to attract derivatives trading from OTC markets”, BIS Quarterly Review, September, pp 33-4.

María Luisa Saavedra and Máximo Jorge Saavedra (2010), Modelos para medir el riesgo de crédito de la banca.

Martin, P., Rey, H. (1999), Financial super-markets: size matters for asset trade.

Mario Bajo Traver and Emilio Rodríguez Alfonso, Gestión activa de una cartera de bonos: Un modelo cuantitativo de duración. Análisis Financiero, 72

Michael G. Kollo (2005), Underwriter Competition And Gross Spreads In The Eurobond Market

Nelson, D and D Foster (1995), Filtering and forecasting with misspecified ARCH models II: making the right forecast with the wrong model.

Nelson, Charles R. and Siegel, Andrew F. (1987). "Parsimonious modeling of yield curves".

Perry, G., \& Servén, L. (2001). La volatilidad Macroeconomica en América Latina: causas ysoluciones. La nueva Agenra de América Latina, 75-91.

Perry, G., \& Servén, L. (2001). La volatilidad Macroeconomica en América Latina: causas y soluciones. La nueva Agenra de América Latina, 75-91.

Peter G. Dunne Michael J. Moore Richard Portes (2011), Benchmark Status in FixedIncome Asset Markets.

Ravi Bansal and Hao Zhou (2001), Term Structure of the interest rates with Regime Shifts.

Triennial Central Bank Survey: OTC interest rate derivatives turnover. (2016),

Available (2017): https://www.bis.org/publ/rpfx18.htm

Triennial Central Bank Survey of foreign exchange and derivatives market activity in 2013

Available (2015): https://www.bis.org/publ/rpfx13.htm

Tse, Y., \& Tsui, C. (2002). A multivariate generalized autoregressive conditional heteroscedasticity model with time-varying correlations. 
Vasicek, Oldrich A. and Fong, H. Gifford (1982). "Term structure modeling using exponential splines".

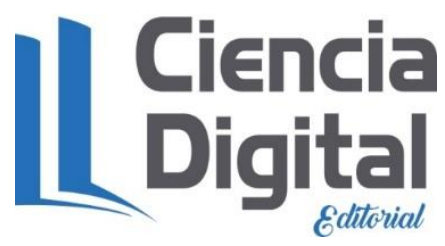




\section{Para citar el artículo indexado}

Santillan Pashma, A. R. (2021). Steadiness of expectation theory measured by swaption curve . AlfaPublicaciones, 3(2.1), 6-26. https://doi.org/10.33262/ap.v3i2.1.46

\section{\Ciencia}

El artículo que se publica es de exclusiva responsabilidad de los autores y no necesariamente reflejan el pensamiento de la Revista Alpha Publicaciones.

El artículo queda en propiedad de la revista y, por tanto, su publicación parcial y/o total en otro medio tiene que ser autorizado por el director de la Revista Alpha Publicaciones.
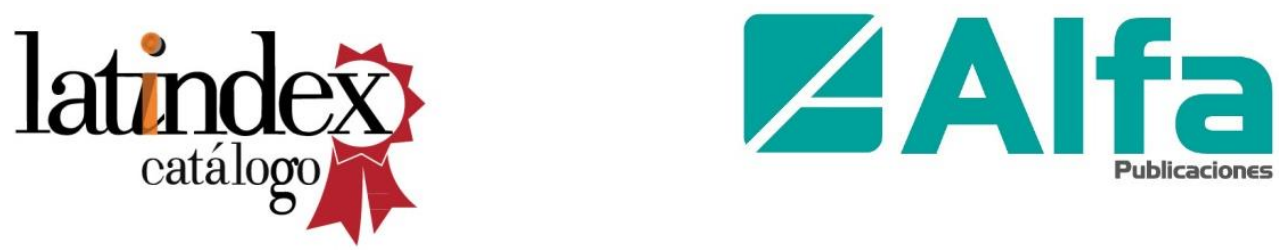